\title{
INCENTIVES FOR INDEPENDENT ANTI-CORRUPTION EXPERTS OF NORMATIVE LEGAL ACTS AND THEIR PROJECTS
}

\author{
Vladislav Yu. Turanin, Sergey A. Rubanov, Yuliya S. Gusakova, \\ Marina A. Sorokoletova, Anastasiya A. Beletskaia \\ Belgorod State University, 85 Pobeda Street, Belgorod, the Belgorod region, 308015, Russia \\ turanin@mail.ru
}

\begin{abstract}
The article is devoted to the problem of incentives for independent anti-corruption experts conducting examination of normative legal acts and their projects. In case the expert is an employee of a legal entity, which is accredited for conducting independent anti-corruption examinations, the system of measures of financial incentives on the part of the employer is proposed (bonuses). An initiative on the possibility of material incentives for independent anti-corruption experts for normative legal acts and their projects, associated with non-profit organizations, has been introduced. The head-note about the importance of nonfinancial incentives for experts with free training courses and seminars, awards, career prospects is suggested. It is noted that the measures presented will increase the effectiveness of independent anticorruption expert activity.
\end{abstract}

Keywords: corruption, expert, independent anti-corruption expertise, regulatory legal act, draft regulatory legal act, incentives.

\section{INTRODUCTION}

The problem of measures against corruption is very actively studied in the works of various Russian and foreign scientists: K. Darden [1], M. Johnston [2], P. De Leon [3] and others. These studies serve as a theoretical basis for the adoption of a number of normative acts that regulate various aspects of anticorruption activities. In particular, the Russian Federation recently adopted the Federal Law No. 172-FZ, dated July 17, 2009, "On Anti-Corruption Examination of Regulatory Legal Acts and Draft Normative Legal Acts", which defines the status of independent anti-corruption experts in normative legal acts and their projects [4].

Concerning the efficiency and effectiveness of the work of independent anti-corruption experts for normative legal acts and their projects, lively discussions have recently been springing up in the scientific community. In particular, in foreign countries, much attention is paid to the need of the unity of approaches to the examination, as well as the systemic training of personnel in this field [5, p.24]. New training courses in the field of forensic expertise are actively being developed [6, c.13]. The problem of stimulating of independent anti-corruption experts is important for the Russian Federation, since in the Federal Law No. 172-FZ, dated July 17, 2009, "On Anti-Corruption Expertise of Normative Legal Acts and Draft Normative Legal Acts" this examination is perceived only as an initiative study.

\section{METHODS}

Various general scientific methods and methods of logical cognition are used in the work. Methods of analysis and synthesis were applied to the study of nature of independent anti-corruption expertise of normative legal acts and their projects. Systemic and structural, functional and formal-logical approaches were used to identify the specifics of the formation of a system for encouraging independent anti-corruption experts of normative legal acts and their projects. The use of formal and legal and comparative and legal methods made it possible to carry out an essential and comparative analysis of measures to stimulate experts and draw a conclusion about the need for their implementation.

\section{DISCUSSION AND RESULTS}


The word stimulus comes from the Latin stimulus, which was previously literally interpreted as "a stick for animals to be driven by". At present, incentives are various means that stimulate the activity (similar in meaning to the words push, impulse, encouragement) [7, p. 865]. In other words, the general meaning of the lexeme stimulus is preserved, but the connotation changed from negative to a positive one. Stimuli are directly related to positive motives, they are associated with incentives, which, as we see, were not previously envisaged.

Stimulation is a fairly effective way of influencing a person, aimed at creating a situation that forces him/her to act in a strictly defined way.

D.S. Kuznetsova notes that "stimulation, being a purely sociocultural phenomenon, is a process of identifying and creating conditions (incentives) aimed at motivating the labor motive. Stimulus (external motivation for action, push, trigger) is any benefit for possession of which it is necessary to carry out some labor activity" [8].

It should be noted that the problem of incentives in the field of law is quite actively investigated in the works of many well-known Russian and foreign scholars. Stimulation is one of the important means which is an additional motivation of an independent anti-corruption expert to carry out his/her activities. It's not a secret that independent anti-corruption expert activity significantly legs behind now. Despite the fact that more than two thousand independent experts authorized to carry out anti-corruption expertise for normative legal acts and their projects - individuals and more than three hundred legal entities - have been accredited on the territory of the Russian Federation, only a few of them are actually involved in this process. Unfortunately, at present, many people think that the status of an independent anti-corruption expert is just PR which allows the expert to stand out among colleagues in certain situations. The certificate of accreditation of a person as an independent anti-corruption expert for normative legal acts and their projects issued by the Ministry of Justice of the Russian Federation does not oblige an accredited person to carry out this activity, but only grants him such a right. As we see, not all of them use this right, almost due to the fact that there are no incentives for carrying out this work (at present an independent anti-corruption examination of normative legal acts and their projects is an initiative study carried out by the expert at the expense of own funds). Often the initial interest in expert activities fades due to various reasons: employment, routine, lack of motivation, etc. At the same time, the importance and need for an independent anti-corruption expertise of normative legal acts and their projects are beyond doubt.

In order to overcome the existing negative situation, from our point of view, effective measures are needed that will give new impetus to the work of independent anti-corruption experts. What incentive options can be applied in this case? Independent anti-corruption experts S.V. Markiyanov and E.A. Yegorycheva note that "the methods of stimulating independent experts may be different, but the search for options for motivating experts, increasing their interest in conducting expert examinations today is relevant (and it is not necessary to encourage experts financially, it is sufficient to react to the results of their work)" [9, p. 37]. It should be noted that the authors raise an important problem that exists in practice: indeed, often, the conclusions of independent anti-corruption experts are perceived by the draftspeople of normative legal acts as certain optional elements of the law-making process.

And the experts do not receive feedback to every conclusion. At the same time, we can not agree with S.V. Markiyanov and E.A. Yegorycheva's point of view that the reaction to expert's conclusions is an incentive for his/her activities, almost the only necessary stimulus. Such a reaction must follow the requirements of the law. Part 3 of Article 5 of the Federal Law No. 172-FZ, dated July 17, 2009, "On Anti-Corruption Examination of Regulatory Legal Acts and Draft Normative Legal Acts" provides that the conclusion of an independent anti-corruption expert, in spite of its recommendatory nature, "is a subject to mandatory review by the body, organization or official to whom it was sent within thirty days from the date it was received".

The impact of any incentive should be based on the application of positive measures of moral and material encouragement. We have already noted that "the system of stimulating the activities of independent anticorruption experts (moral and material) is necessary" [10, p.98]. And if material encouragement can be 
both a permanent and a temporary incentive, the non-material incentive is of a strategic nature, it is aimed at a long-term perspective, which underlines its special significance.

\section{RESULTS}

The organizational and legal mechanism for stimulating independent anti-corruption experts of normative legal acts and their projects can be presented on the basis of its types (material and non-material), subjects, as well as the need for legal provision of proposed incentives.

Accordingly, the material stimulation of the work of an independent anti-corruption expert can be carried out in two ways:

- firstly, it can be implemented by the employer if the expert is an employee of a legal entity that is accredited to conduct independent anti-corruption expertise of normative legal acts and their projects. In this case, such incentives as bonuses, bonuses to the salary stipulated in the employee's employment contract are applicable;

- secondly, material incentives for independent anti-corruption experts are also possible through non-profit organizations (for example, in the case of the creation of a non-commercial partnership "Association of Independent Anti-Corruption Experts").

Unfortunately, with the financial stimulation of independent anti-corruption experts for normative legal acts and their projects, it is unlikely that the contract for provision of services written in art. 779 of the Civil Code of the Russian Federation (which is intended for similar public relations), as their studies have an initiative character.

Non-material incentives may include:

- firstly, free training courses for independent anti-corruption experts, organized by the territorial bodies of the Ministry of Justice of the Russian Federation, as well as training seminars with the involvement of leading experts in this field, aimed primarily at learning the existing problems in expert activity, innovations in the Russian legislation system, and, of course, on the exchange of experience in the implementation of independent anti-corruption expertise for normative legal acts and their projects;

- secondly, the awarding of an expert is the issuance of an official document that is a proof of his success and achievements (for example, gratitude, an honorary letter of a territorial body of the Ministry of Justice of the Russian Federation), given to the best specialist (or the best specialists) most actively involved in this process, qualification;

- thirdly, the formation of career prospects for the main place of work, due to accreditation as an independent anti-corruption expert, and also related to further development of skills in this field.

From the point of view of legal support for the promotion of independent anti-corruption experts in normative legal acts and their projects, we believe that its mechanisms can be defined both at the federal and regional levels.

\section{CONCLUSION}

The combination of material and non-material stimulation of the work of an independent anti-corruption expert for normative legal acts and their projects will strengthen both his/her interest in the matter and the intention for self-realization. And this, in turn, will serve as a prerequisite for increasing the effectiveness of independent expert activity, creating a full-fledged working expert community, characterized by high quality of labor results.

\section{CONFLICT OF INTEREST}

The authors confirm that the information provided in the article does not contain a conflict of interest. 


\section{AKNOWLEDGEMENT}

This article was prepared within the framework of the scientific project No. 17-13-31005 / 17 of the Russian Foundation for Basic Research "Improvement of the Organizational and Legal Mechanism for the Implementation of an Independent Anti-Corruption Expertise of Normative Legal Acts and their Projects at the Regional Level".

\section{REFERENCES}

[1] Darden, K., 2008. The Integrity of Corrupt States: Graft as an Informal State Institution. Politics and Society, $36(1): 35-59$.

[2] Johnston, M., Syndromes of Corruption. Wealth, Power and Democracy. New York: Cambridge University Press. 2005. 267 p.

[3] De Leon, P., Thinking about Political Corruption. New York: Sharpe, 1993. 256 p.

[4] Federal'nyj zakon ot 17 ijulja 2009 g. № 172-FZ «Ob Antikorrupcionnoj Jekspertize Normativnyh Pravovyh Aktov i Proektov Normativnyh Pravovyh Aktov» // Sobranie Zakonodatel'stva Rossijskoj Federacii, 2009, № 29, st. 3609. (in Russian) (Federal Law No. 172-FZ, dated July 17, 2009, On Anti-Corruption Examination of Regulatory Legal Acts and Draft Normative Legal Acts // Collection of Legislation of the Russian Federation, 2009, No. 29, art. 3609.)

[5] Lockyer, B., 2003. State of the California. Office of the Attorney General. - Aug. P.24.

[6] Mennel, J., 2006. The Future of Forensic and Crime Scene Science. Forensic Science International. 157. P.13

[7] Komlev, N.G. Slovar' Inostrannyh Slov. M., 2000. 1308 s. (in Russian)

[8] Kuznecova, D.S. Osobennosti Sistemy Stimulirovanija Specialistov Jekonomicheskogo Profilja // URL: https://cyberleninka.ru/article/v/osobennosti-sistemy-stimulirovaniya-spetsialistov-ekonomicheskogoprofilya (date of access: 03.02.2018) (in Russian)

[9] Markijanov, S.V., Egorycheva, E.A. Problemy Provedenija Nezavisimoj Antikorrupcionnoj Jekspertizy: Mnenie i Predlozhenija Nezavisimyh Jeksper-tov // Monitoring Pravoprimenenija. 2012. №1. S. 36-38. (in Russian)

[10] Tonkov, E.E., Turanin, V.Ju. Nezavisimaja Antikorrupcionnaja Jekspertiza Normativnyh Pravovyh Aktov $i$ ih Proektov: Problemy Osushhestvlenija i Vozmozhnosti ih Preodolenija // Vestnik Voronezhskogo gosudarstvennogo universiteta. Ser. Pravo. 2015. № 1 (20). S. 94-99. (in Russian) 